\title{
Comparative seismic performance of Flat slab with peripheral beam provided infill and shear wall panel at different heights
}

\author{
Priyanka Vijaykumar Baheti ${ }^{1}$, D.S.Wadje ${ }^{2}$, G.R.Gandhe ${ }^{3}$ \\ P.G. student of Structural Engineering, Deogiri Institute of Engineering \& Management studies ${ }^{1}$, Assistant \\ Professor of Civil Engineering Department, Deogiri Institute of Engineering \& Management studies ${ }^{2}$, Head of \\ Civil Engineering Department, Deogiri Institute of Engineering \& Management studies ${ }^{3}$
}

\begin{abstract}
The main objective of this paper is to study the behavior of flat slab structure under equivalent static analysis and compare the behavior with a shear wall panel and infill wall panel provided at centre and corner of building. The analysis is carried out in E-tabs software. To achieve the objective flat slab peripheral beam provided at structure and infill wall panel and shear wall panel provided different heights such as $G+4, G+8$, G+12 are modeled and analyzed In this paper it is proposed to carry out static analysis to study the behavior of flat slab with peripheral beam structures till collapse and identify the weaknesses under seismic loading. The natural time period increases as the height of building (No.of stories) increases, irrespective of type of wall panel provided at different stories, flat slab structure. In comparison with the shear wall panel and infill wall panel provided to flat slab with peripheral beam of building, the time period, deflection, drift and base shear considered for analysis. For analysis seismic zone IV and medium soil condition are used.
\end{abstract}

Key Words: Infill wall, shear wall, shear wall and infill wall provide for different storey, Earthquake Analysis, IS 1893:2002 provisions, flat slab with peripheral of beam.

\section{Introduction}

Recent earthquakes in which many concrete structures have been severely damaged or collapsed, have indicated the need for evaluating the seismic adequacy of buildings. About $60 \%$ of the land area of our country is susceptible to damaging levels of seismic hazard. We can't avoid future earthquakes, but safe building construction practices can certainly reduce the extent of damage and loss. Flat-slab is one of the most widely used systems in reinforced concrete construction because of its high degree of functional efficiency. It uses simple formwork and reinforcing arrangements, and requires the least story height. However the structural efficiency of the flat-slab construction is hindered by its poor performance under earthquake loading. This gives rise to excessive deformations that cause damage in non-structural members even when subjected to earthquakes of moderate intensity.

Although the acceleration in flat slab structures are reduced due to its flexibility, the storey drift increases significantly and are many times exceed the permissible limits specified by the code. This may make the flat slab structure unserviceable during earthquakes. The natural time period increases as the height of building (No. of stories) increases, irrespective of type of building viz. conventional structure, flat slab structure. In comparison with the flat slab provided peripheral beam of building and infill wall and shear wall panel are provided at $\mathrm{G}+4, \mathrm{G}+8$ and $\mathrm{G}+12$ storey. The time period, deflection, drift and base shear parameters are considered for analysis. For the analysis equivalent static analysis methods, modeling were done in ETAB software, medium soil condition and seismic zone IV are considered.

\section{Methodology}

Common practice of design and construction is to support the slabs by beams and support the beams by columns. This may be called as beam-slab construction. The beams reduce the available net clear ceiling height. Hence in warehouses, offices and public halls sometimes beams are avoided and slabs are directly supported by columns. These types of construction are aesthetically appealing also. These slabs which are directly supported by columns are called Flat Slabs. The column head is sometimes widened so as to reduce the punching shear in the slab. The widened portions are called column heads. The column heads may be provided with any angle from the consideration of architecture but for the design, concrete in the portion at $45^{\circ}$ on either side of vertical only is considered as effective for the design. Moments in the slabs are more near the column. Hence the slab is thickened near the columns by providing the drops as shown in figure 2.3. Sometimes the drops are called as capital of the column. Thus we have the following types of flat slabs: 


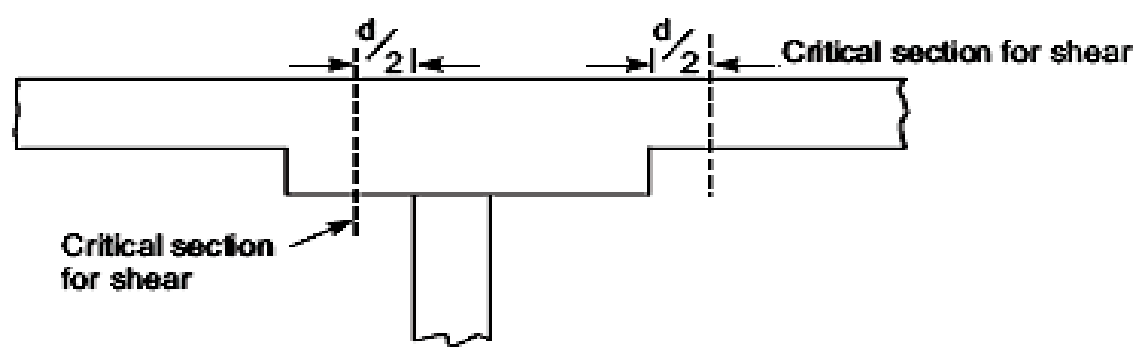

Figure 2.1: Slab with Drop and Column without Column Head

(i) Slabs without drop and column head

(ii) Slabs without drop and column with column head

(iii) Slabs with drop and column without column head (Figure 2.1).

(iv) Slabs with drop and column head as shown in (Figure 2.2)

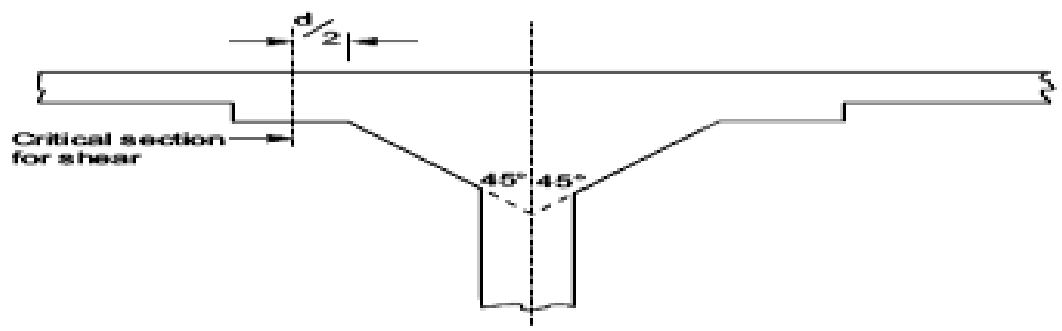

Figure 2.2: Slab with Drop and Column with Column Head

The portion of flat slab that is bound on each of its four sides by centre lines of adjacent columns is

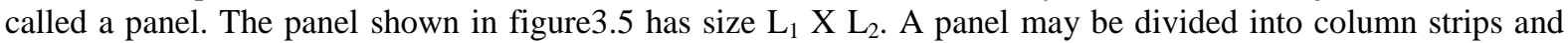
middle strips. Column Strip means a design strip having a width of $0.25 \mathrm{~L}_{1}$ or $0.25 \mathrm{~L}_{2}$, whichever is less. The remaining middle portion which is bound by the column strips is called middle strip. Figure 3.5 shows the division of flat slab panel into column and middle strips in the direction $\mathrm{y}$.

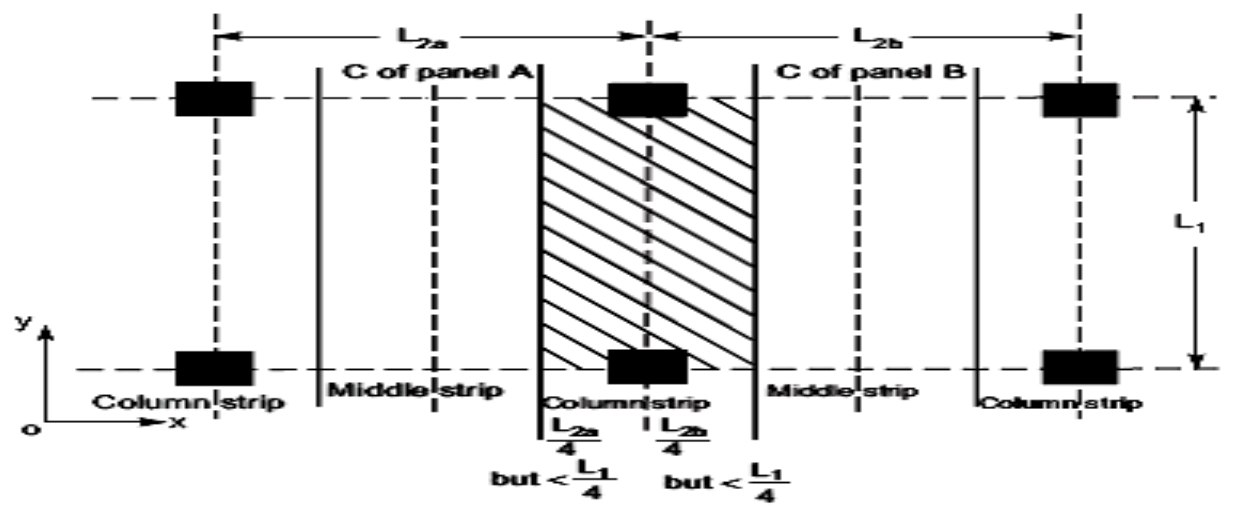

Figure 2.3: Panel Column Strips and Middle Strip is Y-Direction

\subsection{The seismic analysis methods}

The seismic analyses methods so far used in estimating the demand on the structure can be classified in the following four groups

I) Linear Static Analysis

II) Linear Dynamic Analysis

III) Nonlinear Static Analysis

V) Nonlinear Dynamic Analysis.

It is seen from the basics of the Structural static that the response of the structure can be estimated as the sum of modal responses. For majority of the structures, consideration of first three or four modal contributions yields sufficiently accurate results. This forms the basis for all the above mentioned analysis procedures.

I) Linear equivalent static method:

The linear static method also known as Equivalent Static Method is used to estimate the demand for the buildings whose response is particularly dominated by the first mode and expected to behave in elastic range. 


\subsection{General}

\section{Problem statement}

The main objective of the analysis is to study the seismic behavior of flat slab provided peripheral beam of structure under equivalent analysis and compare the behavior with an infill wall and shear wall panel provided at centre and corner. The $\mathrm{G}+4, \mathrm{G}+8, \mathrm{G}+12$ storey height as shown in Figure 3.1, Figure 3.2, and Figure 3.3. This equivalent static analysis is carried out using E-tab software. The thickness of wall panel is $230 \mathrm{~mm}$ and shear wall panel is $150 \mathrm{~mm}$. The seismic zone IV and medium soil condition also considered for analysis.

\subsection{Modeling of Building}

For the comparative analysis, flat slab with peripheral of beam of buildings are considered, one is a typical infill wall and shear wall panel provided at $\mathrm{G}+4, \mathrm{G}+8, \mathrm{G}+12$ storey for Flat Slab with peripheral beam of building. The building models which are used in this paper are $(\mathrm{G}+12)$. The total plan dimension of building is $25 \mathrm{~m} \times 25 \mathrm{~m}$. The above buildings are analyzed for firstly with infill wall and shear wall panels provided at different storey and then these buildings are analyzed by equivalent static analysis for flat slab buildings. The designation used for the building models is as given in following Table 1.

Table 3.1: Description of a building model

\begin{tabular}{|c|l|c|}
\hline Model No. & \multicolumn{1}{|c|}{ Type of Structure } & Designation \\
\hline 1 & $\begin{array}{l}\text { G+4 Storey rectangular Infill wall and shear wall panel of } \\
\text { flat slab without periphery of beam }\end{array}$ & RIW \& RSW G+4 \\
\hline 2 & $\begin{array}{l}\text { G+8 Storey rectangular Infill wall and shear wall panel of } \\
\text { flat slab without periphery of beam }\end{array}$ & RIW \& RSW G+8 \\
\hline 3 & $\begin{array}{l}\text { G+12 Storey rectangular Infill wall and shear wall panel of } \\
\text { flat slab without periphery of beam }\end{array}$ & LIW \& LSW G+4 \\
\hline 4 & $\begin{array}{l}\text { G+4 Storey L shape Infill wall and shear wall panel of flat } \\
\text { slab without periphery of beam }\end{array}$ & LIW \& LSW G+8 \\
\hline 5 & $\begin{array}{l}\text { G+8 Storey L shape Infill wall and shear wall panel of flat } \\
\text { slab without periphery of beam }\end{array}$ & LIW \& LSW G+12 \\
\hline 6 & $\begin{array}{l}\text { G+12 Storey L shape Infill wall and shear wall panel of flat } \\
\text { slab without periphery of beam }\end{array}$ & \\
\hline
\end{tabular}

Above data and models are used for analysis of structures with respect to different parameters like period, displacement, base shear, capacity of the structure. The general characteristics of the structure are as per Table 4.2 which is given below.

Table 4.2: General Characteristics of the Analyzed Structural Systems

\begin{tabular}{|c|c|c|c|c|c|c|}
\hline $\begin{array}{c}\text { Type of Structural } \\
\text { system }\end{array}$ & $\begin{array}{c}\text { G+4 RIW \& } \\
\text { RSW }\end{array}$ & $\begin{array}{c}\text { G+8 RIW \& } \\
\text { RSW }\end{array}$ & $\begin{array}{c}\text { G+12 RIW \& } \\
\text { RSW }\end{array}$ & $\begin{array}{c}\text { G+4 LIW \& } \\
\text { LSW }\end{array}$ & $\begin{array}{c}\text { G+8 LIW \& } \\
\text { LSW }\end{array}$ & $\begin{array}{c}\text { G+12 LIW } \\
\& \text { LSW }\end{array}$ \\
\hline Slab (mm) & \multicolumn{6}{|c|}{$200 \mathrm{~mm}$ thick } \\
\hline Column (mm) & \multicolumn{6}{|c|}{$600 \times 600 \mathrm{~mm}$} \\
\hline Drop panel $(\mathrm{m})$ & \multicolumn{6}{|c|}{$1800 \mathrm{~mm}$} \\
\hline Drop $(\mathrm{mm})$ & \multicolumn{6}{|c|}{$300 \mathrm{~mm}$ thick } \\
\hline Beam size in $\mathrm{mm}$ & \multicolumn{6}{|c|}{$250 \mathrm{~mm} \times 500 \mathrm{~mm}$} \\
\hline Material Properties & \multicolumn{6}{|c|}{ For Concrete M 25 and For Steel Fe 415} \\
\hline Infill wall & \multicolumn{6}{|c|}{$230 \mathrm{~mm}$ thick } \\
\hline Shear wall & \multicolumn{6}{|c|}{$150 \mathrm{~mm}$ thick } \\
\hline Height of each floor $(\mathrm{m})$ & \multicolumn{6}{|c|}{3} \\
\hline Density $\left(\mathrm{kN} / \mathrm{m}^{2}\right)$ & \multicolumn{6}{|c|}{25} \\
\hline Live load $\left(\mathrm{kN} / \mathrm{m}^{2}\right)$ & \multicolumn{6}{|c|}{4} \\
\hline Floor finish $\left(\mathrm{kN} / \mathrm{m}^{2}\right)$ & \multicolumn{6}{|c|}{1} \\
\hline Seismic Zone & \multicolumn{6}{|c|}{ IV } \\
\hline Soil type & \multicolumn{6}{|c|}{ Medium hard rock } \\
\hline
\end{tabular}



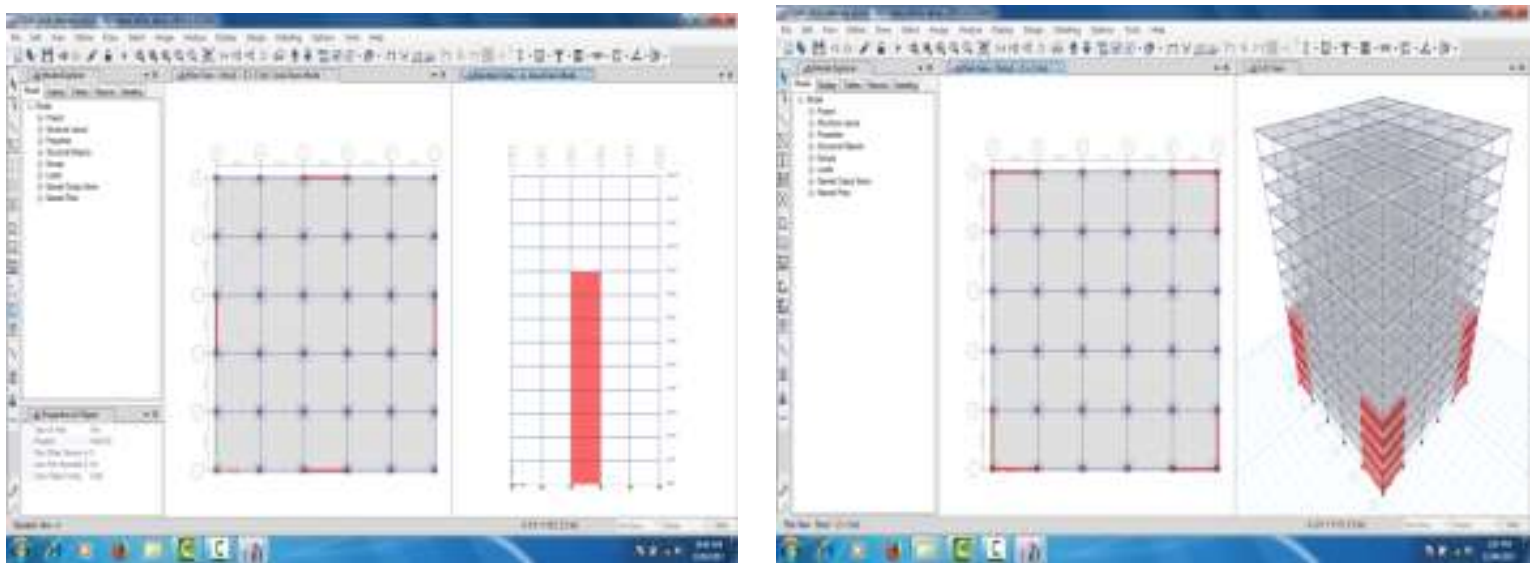

Figure 3.1 Rectangular and L shape Infill and Shear wall panel at G+4, G+8, G+12 storey

\section{4. Result and Discussion:}

The comparative seismic analysis of flat slab without periphery of beam provided Rectangular and L shape infill wall and shear wall panels provided at different location such as centre of periphery of building and corner of building at different storey such as $\mathrm{G}+4, \mathrm{G}+8$ and $\mathrm{G}+12$ storeys. To better analysis tabular result of parameter such as modal time periods, deflection at top storey, base shear and axial force in Table 4.1 to 4.8.

Table 4.1 Comparison of time period of Rectangular infill wall and shear wall panel at G+4, G+8, $\mathrm{G}+12$ storey

\begin{tabular}{|c|c|c|r|r|r|r|}
\hline Mode No. & \multicolumn{1}{|c|}{$\begin{array}{l}\text { RIW } \\
\text { G+4 }\end{array}$} & \multicolumn{1}{c|}{$\begin{array}{c}\text { RSW } \\
\text { G+4 }\end{array}$} & \multicolumn{1}{c|}{$\begin{array}{c}\text { RIW } \\
\text { G+8 }\end{array}$} & \multicolumn{1}{c|}{$\begin{array}{c}\text { RSW } \\
\text { G+8 }\end{array}$} & \multicolumn{1}{c|}{$\begin{array}{c}\text { RIW } \\
\text { G+12 }\end{array}$} & \multicolumn{1}{c|}{$\begin{array}{c}\text { RSW } \\
\text { G+12 }\end{array}$} \\
\hline $\mathbf{1}$ & 1.747 & 2.214 & 0.935 & 2.118 & 0.597 & 2.116 \\
\hline $\mathbf{2}$ & 1.743 & 2.212 & 0.933 & 2.117 & 0.597 & 2.116 \\
\hline $\mathbf{3}$ & 1.598 & 1.833 & 0.813 & 1.597 & 0.374 & 1.597 \\
\hline $\mathbf{4}$ & 0.555 & 0.758 & 0.338 & 0.676 & 0.261 & 0.605 \\
\hline $\mathbf{5}$ & 0.554 & 0.757 & 0.338 & 0.676 & 0.231 & 0.605 \\
\hline $\mathbf{6}$ & 0.509 & 0.633 & 0.262 & 0.566 & 0.231 & 0.432 \\
\hline $\mathbf{7}$ & 0.31 & 0.449 & 0.26 & 0.378 & 0.218 & 0.299 \\
\hline $\mathbf{8}$ & 0.31 & 0.448 & 0.233 & 0.377 & 0.206 & 0.299 \\
\hline $\mathbf{9}$ & 0.284 & 0.387 & 0.233 & 0.29 & 0.192 & 0.267 \\
\hline $\mathbf{1 0}$ & 0.266 & 0.296 & 0.221 & 0.267 & 0.192 & 0.239 \\
\hline $\mathbf{1 1}$ & 0.238 & 0.295 & 0.221 & 0.246 & 0.179 & 0.239 \\
\hline $\mathbf{1 2}$ & 0.238 & 0.269 & 0.22 & 0.246 & 0.169 & 0.22 \\
\hline
\end{tabular}

Table 4.2 Comparison of time period in seconds of $\mathrm{L}$ shape infill wall and shear wall panel at $\mathrm{G}+4$, $\mathrm{G}+8, \mathrm{G}+12$ storey

\begin{tabular}{|c|c|c|c|c|c|c|}
\hline Mode No. & $\begin{array}{l}\text { LIW } \\
\text { G+4 }\end{array}$ & $\begin{array}{r}\text { LSW } \\
\text { G+4 }\end{array}$ & $\begin{array}{l}\text { LIW } \\
\text { G+8 }\end{array}$ & $\begin{array}{c}\text { LSW } \\
\mathbf{G + 8} \\
\end{array}$ & $\begin{array}{c}\text { LIW } \\
\text { G+12 }\end{array}$ & $\begin{array}{l}\text { LSW } \\
\text { G+12 }\end{array}$ \\
\hline 1 & 1.722 & 2.026 & 0.86 & 1.764 & 0.287 & 1.774 \\
\hline 2 & 1.719 & 2.025 & 0.858 & 1.762 & 0.286 & 1.773 \\
\hline 3 & 1.574 & 1.711 & 0.771 & 1.192 & 0.266 & 1.144 \\
\hline 4 & 0.548 & 0.668 & 0.267 & 0.609 & 0.235 & 0.465 \\
\hline 5 & 0.547 & 0.667 & 0.264 & 0.608 & 0.235 & 0.465 \\
\hline 6 & 0.502 & 0.544 & 0.263 & 0.487 & 0.209 & 0.285 \\
\hline 7 & 0.306 & 0.417 & 0.236 & 0.31 & 0.199 & 0.269 \\
\hline 8 & 0.305 & 0.416 & 0.236 & 0.309 & 0.194 & 0.239 \\
\hline
\end{tabular}


Comparative seismic performance of Flat slab with peripheral beam provided infill and shear wall ..

\begin{tabular}{|r|r|r|r|r|r|r|}
\hline $\mathbf{9}$ & 0.28 & 0.33 & 0.233 & 0.269 & 0.178 & 0.239 \\
\hline $\mathbf{1 0}$ & 0.269 & 0.283 & 0.21 & 0.24 & 0.178 & 0.221 \\
\hline $\mathbf{1 1}$ & 0.24 & 0.283 & 0.201 & 0.24 & 0.16 & 0.221 \\
\hline $\mathbf{1 2}$ & 0.24 & 0.27 & 0.195 & 0.235 & 0.16 & 0.21 \\
\hline
\end{tabular}

Table 4.3 Comparison of deflection in mm of Rectangular shape infill wall and shear wall panel at $\mathrm{G}+4, \mathrm{G}+8$, G+12 storey

\begin{tabular}{|c|c|c|c|c|c|c|}
\hline $\begin{array}{c}\text { Height in } \\
\mathbf{m}\end{array}$ & $\begin{array}{c}\text { RIW } \\
\mathbf{G + 4}\end{array}$ & $\begin{array}{c}\text { RSW } \\
\mathbf{G + 4}\end{array}$ & $\begin{array}{c}\text { RIW } \\
\mathbf{G + 8}\end{array}$ & $\begin{array}{c}\text { RSW } \\
\mathbf{G + 8}\end{array}$ & $\begin{array}{c}\text { RIW } \\
\mathbf{G + 1 2}\end{array}$ & $\begin{array}{c}\text { RSW } \\
\mathbf{G + 1 2}\end{array}$ \\
\hline $\mathbf{3 9}$ & 51.084 & 57.563 & 33.712 & 54.109 & 17.745 & 54.638 \\
\hline $\mathbf{3 6}$ & 48.505 & 55.423 & 29.382 & 51.951 & 15.873 & 51.256 \\
\hline $\mathbf{3 3}$ & 44.35 & 52.043 & 22.268 & 48.509 & 14.002 & 47.408 \\
\hline $\mathbf{3 0}$ & 38.707 & 47.49 & 13.15 & 43.919 & 12.145 & 43.175 \\
\hline $\mathbf{2 7}$ & 31.81 & 41.947 & 5.418 & 38.669 & 10.318 & 38.574 \\
\hline $\mathbf{2 4}$ & 23.922 & 35.612 & 4.529 & 33.646 & 8.546 & 33.669 \\
\hline $\mathbf{2 1}$ & 15.366 & 28.697 & 3.666 & 28.49 & 6.853 & 28.552 \\
\hline $\mathbf{1 8}$ & 6.804 & 21.535 & 2.843 & 23.261 & 5.271 & 23.34 \\
\hline $\mathbf{1 5}$ & 0.63 & 15.082 & 2.083 & 18.093 & 3.832 & 18.172 \\
\hline $\mathbf{1 2}$ & 0.44 & 11.079 & 1.407 & 13.143 & 2.568 & 13.211 \\
\hline $\mathbf{9}$ & 0.272 & 7.413 & 0.837 & 8.596 & 1.516 & 8.647 \\
\hline $\mathbf{6}$ & 0.134 & 4.115 & 0.396 & 4.676 & 0.713 & 4.707 \\
\hline $\mathbf{3}$ & 0.039 & 1.479 & 0.109 & 1.642 & 0.195 & 1.654 \\
\hline $\mathbf{0}$ & 0 & 0 & 0 & 0 & 0 & 0 \\
\hline
\end{tabular}

Table 4.4 Comparison of deflection in mm of $\mathrm{L}$ shape infill wall and shear wall panel at G+4, G+8, G+12 storey

\begin{tabular}{|c|c|c|c|c|c|c|}
\hline $\begin{array}{c}\text { Height in } \\
\mathbf{m}\end{array}$ & $\begin{array}{c}\text { LIW } \\
\mathbf{G + 4}\end{array}$ & $\begin{array}{c}\text { LSW } \\
\mathbf{G + 4}\end{array}$ & $\begin{array}{c}\text { LIW } \\
\mathbf{G + 8}\end{array}$ & $\begin{array}{c}\text { LSW } \\
\mathbf{G + 8}\end{array}$ & $\begin{array}{c}\text { LIW } \\
\mathbf{G + 1 2}\end{array}$ & $\begin{array}{c}\text { LSW } \\
\mathbf{G + 1 2}\end{array}$ \\
\hline $\mathbf{3 9}$ & 51.042 & 56.03 & 31.476 & 49.344 & 4.463 & 48.371 \\
\hline $\mathbf{3 6}$ & 48.465 & 53.623 & 26.797 & 46.551 & 3.998 & 44.577 \\
\hline $\mathbf{3 3}$ & 44.275 & 49.855 & 19.082 & 42.239 & 3.533 & 40.51 \\
\hline $\mathbf{3 0}$ & 38.56 & 44.793 & 9.243 & 36.64 & 3.07 & 36.249 \\
\hline $\mathbf{2 7}$ & 31.561 & 38.64 & 1.345 & 30.755 & 2.613 & 31.825 \\
\hline $\mathbf{2 4}$ & 23.547 & 31.616 & 1.126 & 26.384 & 2.17 & 27.301 \\
\hline $\mathbf{2 1}$ & 14.857 & 23.973 & 0.914 & 22.048 & 1.745 & 22.755 \\
\hline $\mathbf{1 8}$ & 6.193 & 16.161 & 0.713 & 17.751 & 1.348 & 18.281 \\
\hline $\mathbf{1 5}$ & 0.162 & 9.655 & 0.526 & 13.608 & 0.986 & 13.986 \\
\hline $\mathbf{1 2}$ & 0.113 & 6.973 & 0.359 & 9.739 & 0.667 & 9.99 \\
\hline $\mathbf{9}$ & 0.071 & 4.624 & 0.217 & 6.277 & 0.4 & 6.426 \\
\hline $\mathbf{6}$ & 0.036 & 2.555 & 0.106 & 3.371 & 0.193 & 3.444 \\
\hline $\mathbf{3}$ & 0.011 & 0.932 & 0.031 & 1.185 & 0.056 & 1.207 \\
\hline $\mathbf{0}$ & 0 & 0 & 0 & 0 & 0 & 0 \\
\hline
\end{tabular}


Comparative seismic performance of Flat slab with peripheral beam provided infill and shear wall ..

Table 4.5 Comparison of Storey Drift in m of Rectangular shape infill wall and shear wall panel at G+4, G+8, $\mathrm{G}+12$ storey

\begin{tabular}{|c|c|c|c|c|c|c|}
\hline $\begin{array}{c}\text { Height in } \\
\mathbf{m}\end{array}$ & $\begin{array}{c}\text { RIW } \\
\mathbf{G + 4}\end{array}$ & $\begin{array}{c}\text { RSW } \\
\mathbf{G + 4}\end{array}$ & $\begin{array}{c}\text { RIW } \\
\mathbf{G + 8}\end{array}$ & $\begin{array}{c}\text { RSW } \\
\mathbf{G + 8}\end{array}$ & $\begin{array}{c}\text { RIW } \\
\mathbf{G + 1 2}\end{array}$ & $\begin{array}{c}\text { RSW } \\
\mathbf{G + 1 2}\end{array}$ \\
\hline $\mathbf{3 9}$ & 0.00086 & 0.000713 & 0.001443 & 0.00072 & 0.000624 & 0.001127 \\
\hline $\mathbf{3 6}$ & 0.001385 & 0.001127 & 0.002371 & 0.001147 & 0.000624 & 0.001283 \\
\hline $\mathbf{3 3}$ & 0.001881 & 0.001518 & 0.003039 & 0.00153 & 0.000619 & 0.001411 \\
\hline $\mathbf{3 0}$ & 0.002299 & 0.001848 & 0.002578 & 0.00175 & 0.000609 & 0.001534 \\
\hline $\mathbf{2 7}$ & 0.002629 & 0.002112 & 0.000296 & 0.001674 & 0.000591 & 0.001635 \\
\hline $\mathbf{2 4}$ & 0.002852 & 0.002305 & 0.000288 & 0.001719 & 0.000564 & 0.001706 \\
\hline $\mathbf{2 1}$ & 0.002854 & 0.002388 & 0.000274 & 0.001743 & 0.000527 & 0.001737 \\
\hline $\mathbf{1 8}$ & 0.002058 & 0.002151 & 0.000253 & 0.001723 & 0.00048 & 0.001723 \\
\hline $\mathbf{1 5}$ & 0.000063 & 0.001334 & 0.000225 & 0.00165 & 0.000421 & 0.001654 \\
\hline $\mathbf{1 2}$ & 0.000056 & 0.001222 & 0.00019 & 0.001515 & 0.000351 & 0.001521 \\
\hline $\mathbf{9}$ & 0.000046 & 0.001099 & 0.000147 & 0.001307 & 0.000268 & 0.001313 \\
\hline $\mathbf{6}$ & 0.000032 & 0.000879 & 0.000096 & 0.001011 & 0.000173 & 0.001018 \\
\hline $\mathbf{3}$ & 0.000013 & 0.000493 & 0.000036 & 0.000547 & 0.000065 & 0.000551 \\
\hline $\mathbf{0}$ & 0 & 0 & 0 & 0 & 0 & 0 \\
\hline
\end{tabular}

Table 4.6 Comparison of Drift in $m$ of $L$ shape infill wall and shear wall panel at $G+4, G+8, G+12$ storey

\begin{tabular}{|c|c|c|c|c|c|c|}
\hline $\begin{array}{c}\text { Height in } \\
\mathbf{m}\end{array}$ & $\begin{array}{c}\text { LIW } \\
\mathbf{G + 4}\end{array}$ & $\begin{array}{c}\text { LSW } \\
\mathbf{G + 4}\end{array}$ & $\begin{array}{c}\text { LIW } \\
\mathbf{G + 8}\end{array}$ & $\begin{array}{c}\text { LSW } \\
\mathbf{G + 8}\end{array}$ & $\begin{array}{c}\text { LIW } \\
\mathbf{G + 1 2}\end{array}$ & $\begin{array}{c}\text { LSW } \\
\mathbf{G + 1 2}\end{array}$ \\
\hline $\mathbf{3 9}$ & 0.000859 & 0.000802 & 0.001559 & 0.000931 & 0.000155 & 0.001265 \\
\hline $\mathbf{3 6}$ & 0.001397 & 0.001256 & 0.002572 & 0.001437 & 0.000155 & 0.001356 \\
\hline $\mathbf{3 3}$ & 0.001905 & 0.001687 & 0.00328 & 0.001866 & 0.000154 & 0.00142 \\
\hline $\mathbf{3 0}$ & 0.002333 & 0.002051 & 0.002633 & 0.001961 & 0.000152 & 0.001475 \\
\hline $\mathbf{2 7}$ & 0.002671 & 0.002342 & 0.000073 & 0.001457 & 0.000148 & 0.001508 \\
\hline $\mathbf{2 4}$ & 0.002897 & 0.002548 & 0.00007 & 0.001445 & 0.000141 & 0.001515 \\
\hline $\mathbf{2 1}$ & 0.002888 & 0.002604 & 0.000067 & 0.001432 & 0.000132 & 0.001491 \\
\hline $\mathbf{1 8}$ & 0.00201 & 0.002169 & 0.000062 & 0.001381 & 0.000121 & 0.001432 \\
\hline $\mathbf{1 5}$ & 0.000016 & 0.000894 & 0.000056 & 0.00129 & 0.000106 & 0.001332 \\
\hline $\mathbf{1 2}$ & 0.000014 & 0.000783 & 0.000047 & 0.001154 & 0.000089 & 0.001188 \\
\hline $\mathbf{9}$ & 0.000012 & 0.00069 & 0.000037 & 0.000969 & 0.000069 & 0.000994 \\
\hline $\mathbf{6}$ & 0.000008 & 0.000541 & 0.000025 & 0.000728 & 0.000046 & 0.000745 \\
\hline $\mathbf{3}$ & 0.000004 & 0.000311 & 0.00001 & 0.000395 & 0.000019 & 0.000402 \\
\hline $\mathbf{0}$ & 0 & 0 & 0 & 0 & 0 & 0 \\
\hline
\end{tabular}

Table 4.7 Comparison of Base shear in $\mathrm{kN} m$ of $\mathrm{L}$ shape infill wall and shear wall panel at $\mathrm{G}+4, \mathrm{G}+8$, $\mathrm{G}+12$ storey

\begin{tabular}{|c|c|c|c|c|c|c|}
\hline Model type & $\begin{array}{c}\text { RIW } \\
\text { G+4 }\end{array}$ & $\begin{array}{c}\text { RSW } \\
\text { G+4 }\end{array}$ & $\begin{array}{c}\text { RIW } \\
\text { G+8 }\end{array}$ & $\begin{array}{c}\text { RSW } \\
\text { G+8 }\end{array}$ & $\begin{array}{c}\text { RIW } \\
\text { G+12 }\end{array}$ & $\begin{array}{c}\text { RSW } \\
\text { G+12 }\end{array}$ \\
\hline Base shear in kN & 8502.49 & 6693.172 & 16064.73 & 6972.42 & 25278.13 & 7126.25 \\
\hline
\end{tabular}

Table 4.8 Comparison of Base shear in $\mathrm{kN} m$ of $\mathrm{L}$ shape infill wall and shear wall panel at $\mathrm{G}+4, \mathrm{G}+8$, G+12 storey

\begin{tabular}{|c|c|c|c|c|c|c|}
\hline Model type & LIW & LSW & LIW & LSW & LIW & LSW \\
& G+4 & G+4 & G+8 & G+8 & G+12 & G+12 \\
\hline
\end{tabular}


Comparative seismic performance of Flat slab with peripheral beam provided infill and shear wall ..

\begin{tabular}{|c|c|c|c|c|c|c|}
\hline $\begin{array}{c}\text { Base shear in } \\
\text { kN }\end{array}$ & 8736.194 & 7390.961 & 17874.67 & 8646.5 & 28850.96 & 8746.343 \\
\hline
\end{tabular}

\section{Result and Discussion:}

From the Graph No.1 the lesser time period in seconds are found in Rectangular shape G+12 infill wall as compared with shear wall. From Graph No.2 time period was also lesser in infill wall as compared with shear wall panel. When compared with Graph No. 1 and 2 the lesser time period in G+12 infill wall in L shape panel.

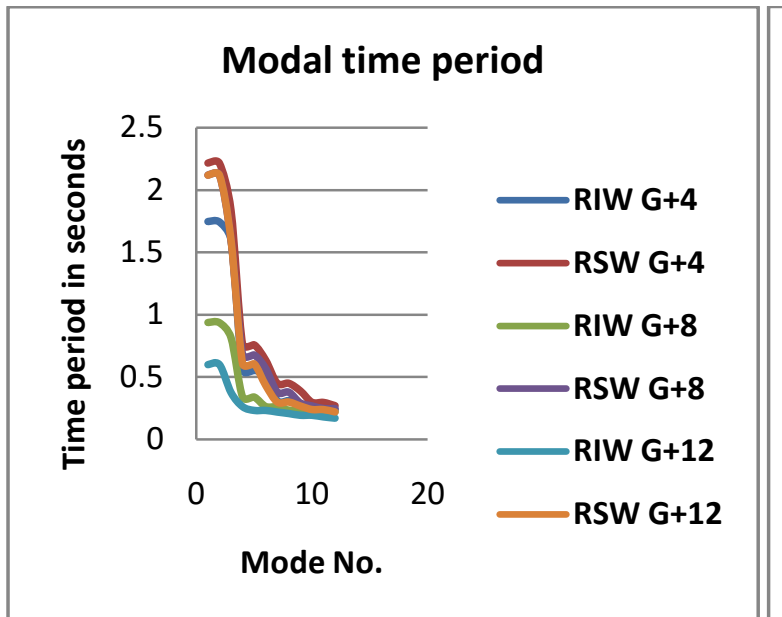

Graph No.1 Comparison of Time period Rectangular panel

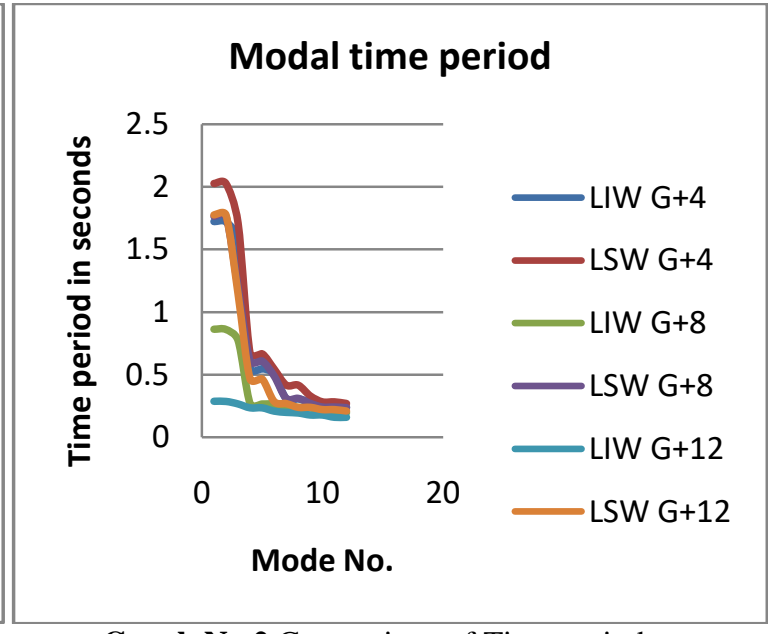

Graph No.2 Comparison of Time period L-shape panel

From the Graph No.3 the lesser Deflection in $\mathrm{mm}$ are found in Rectangular shape G+12 infill wall as compared with shear wall. From Graph No.4 Deflection in mm was also lesser in infill wall as compared with shear wall panel. When compared with Graph No. 1 and 2 the lesser Deflection in G+12 infill wall in L shape panel.

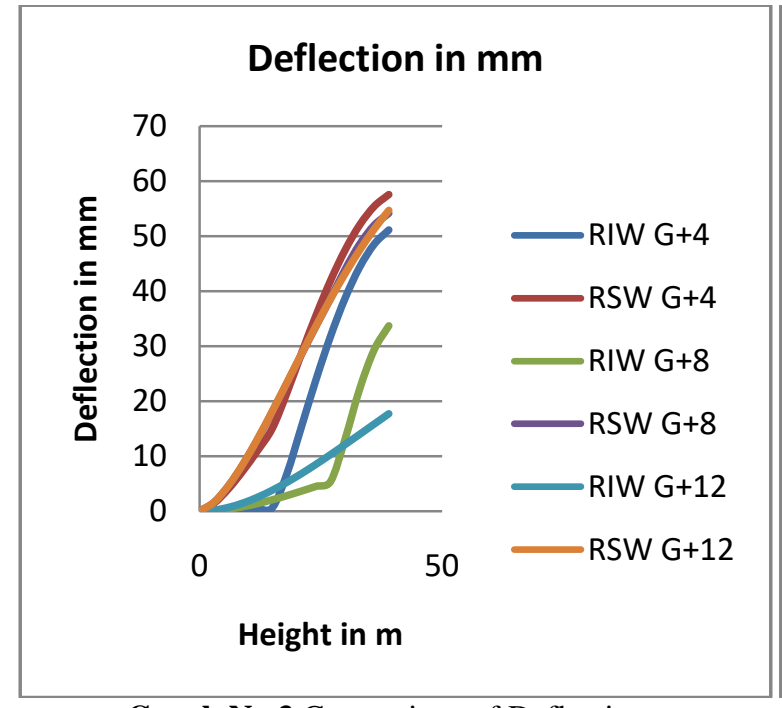

Graph No.3 Comparison of Deflection Rectangular panel

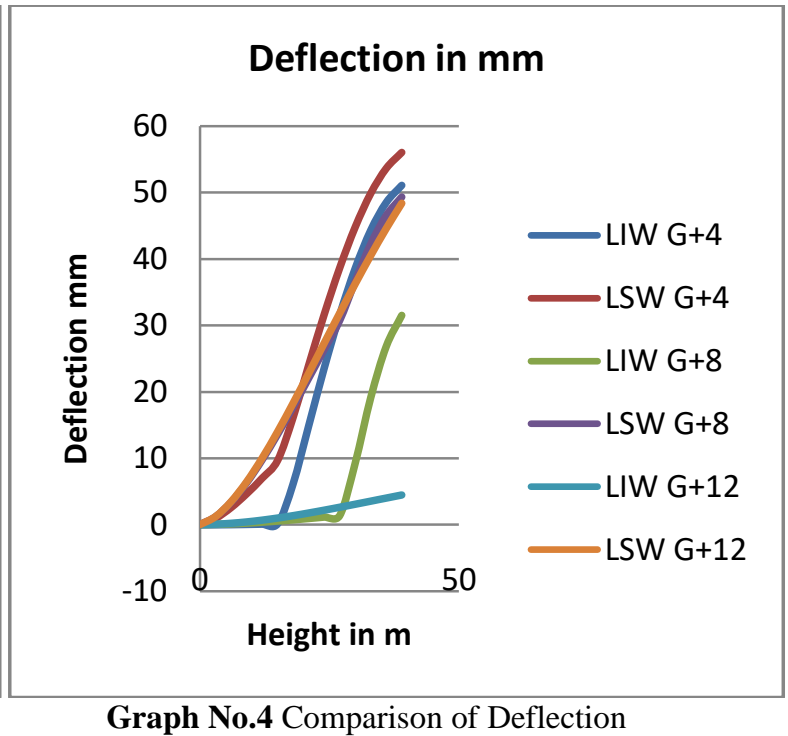

L-shape panel

From the Graph No.5 the lesser Storey drift in $\mathrm{m}$ are found in Rectangular shape G+12 infill wall as compared with shear wall. From Graph No.6 Storey Drift in $\mathrm{m}$ was also lesser in infill wall as compared with shear wall panel. When compared with Graph No. 1 and 2 the lesser Storey Drift in m G+12 infill wall in L shape panel. 


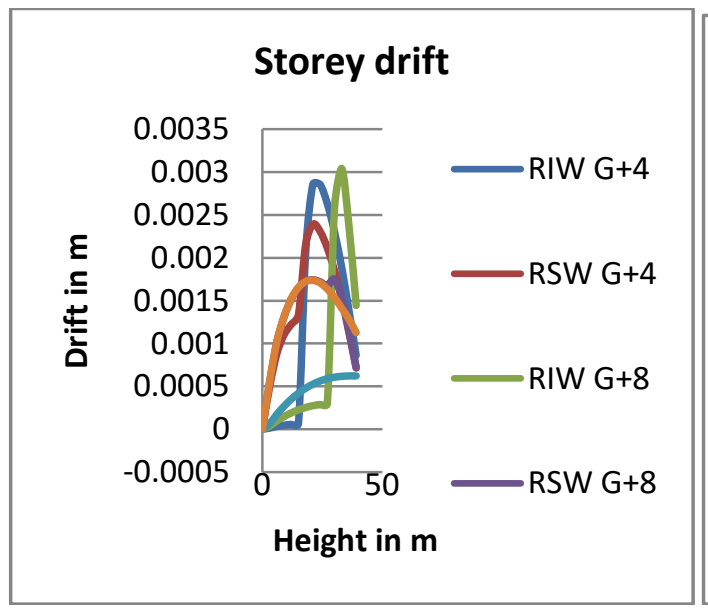

Graph No.5 Comparison of Storey Drift

Rectangular panel

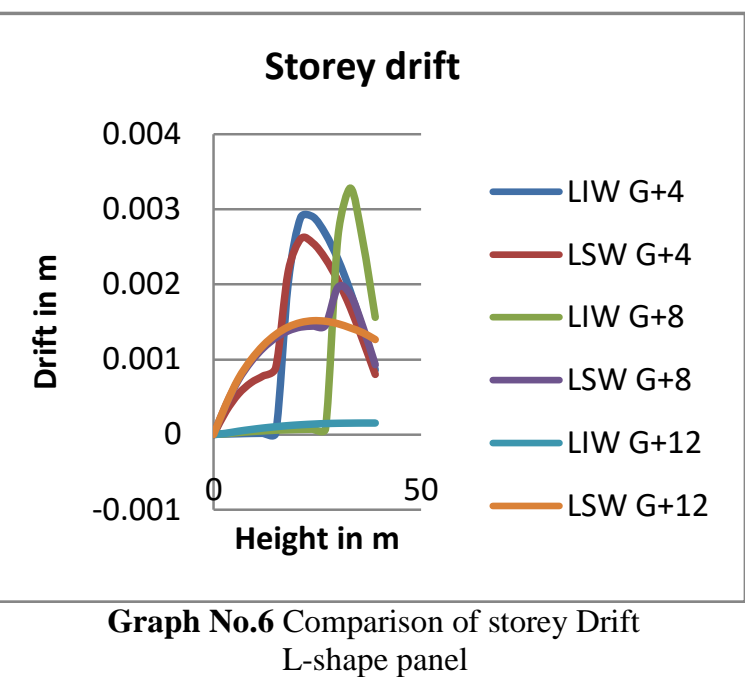

L-shape panel

From the Graph No.7 the greater Base shear in $\mathrm{kN}$ are found in Rectangular shape $\mathrm{G}+12$ infill wall as compared with shear wall. From Graph No.8 Base shear in $\mathrm{kN} \mathrm{mm}$ was also higher in infill wall as compared with shear wall panel. When compared with Graph No. 7 and 8 the lesser Base shear in kN G+12 infill wall in L shape panel.

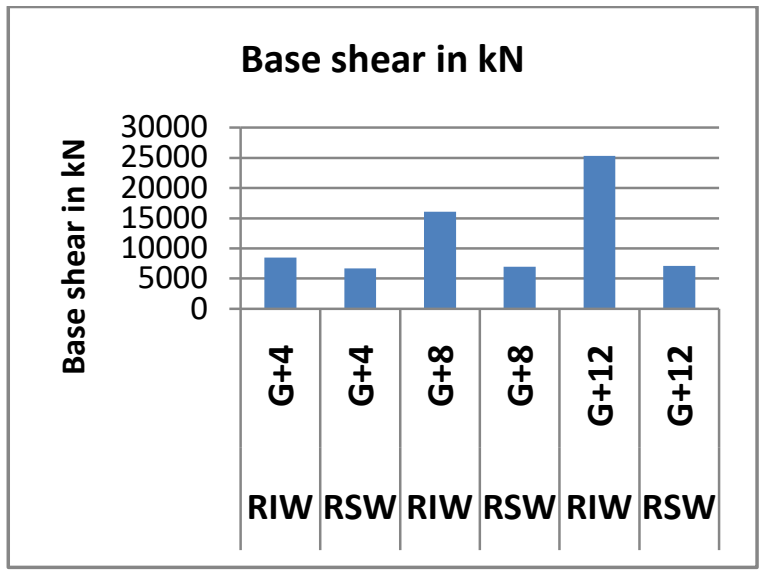

Graph No.7 Comparison of Storey Base shear Rectangular panel

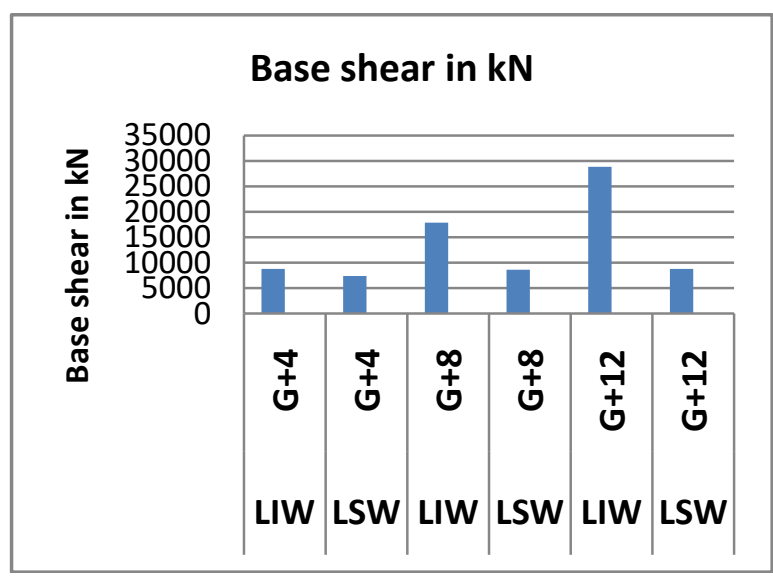

Graph No.8 Comparison of storey Base shear L-shape panel

\section{Conclusion}

Form the above Graph No. 1 to Graph No.8 and equivalent static analysis the L shape Infill wall panel are best suitable for seismic analysis. The time period and deflection in decreases with increases the stiffness of structure.

\section{References}

[1]. Indian standard code for Reinforced Concrete structure IS 456:2000

[2]. Indian standard code for Erath resisting structure IS 1893: 2002 (Part 2)

[3]. A. E. Hassaballa , M. A. Ismaeil , A. N. Alzead, Fa Thelrahman, M. Adam, "Pushover Analysis of Existing 4 Storey RC Flat Slab Building", International Journal of Sciences: Basic and Applied Research IJSBAR)(2014) Volume 16, No 2, pp 242-257

[4]. Sharad P. Desai, Swapnil B. Cholekar "Seismic Behaviour Of Flat Slab Framed Structure With And Without Masonry Infill Wall", International Journal of Engineering Research \& Technology (IJERT) Vol. 2 Issue 7, July - 2013 ISSN: 2278-0181

[5]. Prof. K S Sable, Er. V A Ghodechor, Prof. S B Kandekar, "Comparative Study of Seismic Behavior of Multistory Flat Slab and Conventional Reinforced Concrete Framed Structures", International Journal of Computer Technology and Electronics Engineering (IJCTEE) Volume 2, Issue 3, June 2012

[6]. Ema COELHO, Paulo CANDEIAS, Giorgios ANAMATEROS, Raul ZAHARIA, Fabio TAUCER, Artur V. PINTO, “ASSESSMENT OF THE SEISMIC BEHAVIOUR OF RC FLAT SLAB UILDING STRUCTURES", 13th World Conference on Earthquake Engineering Vancouver, B.C., Canada August 1-6, 2004 Paper No. 2630

[7]. Ms. Kiran parmar, prof. Mazhar dhankot, "Comparative study between dual systems For lateral load resistance in buildings of variable heights", journal of information, knowledge and research in computer engineering" ISSN: 0975 - 6760 NOV 12 TO OCT 13 volume -02 . 